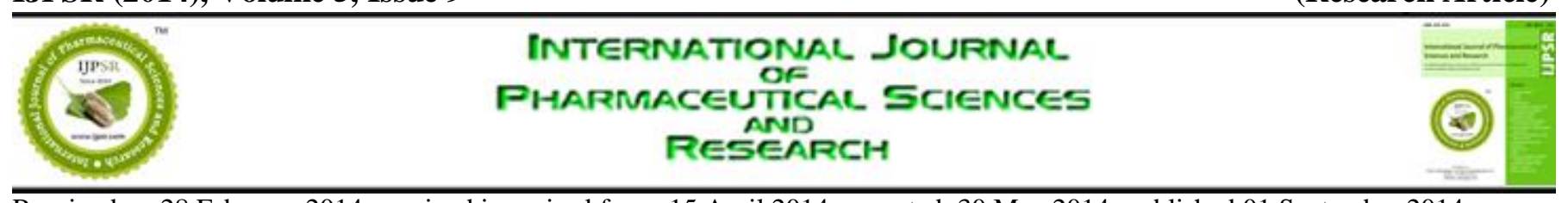

Received on 28 February 2014; received in revised form, 15 April 2014; accepted, 30 May 2014; published 01 September 2014

\title{
METHOD DEVELOPMENT AND VALIDATION OF KETOROLAC TROMETHAMINE IN TABLET FORMULATION BY RP-HPLC METHOD
}

\author{
Dhiraj A. Khairnar *, Chetan S. Chaudhari and Sanjay P. Anantwar
}

Department of Pharmaceutics, M.V.P. Samaj’s College of Pharmacy, Near K.T.H.M. Campus, Gangapur Road, Nasik - 422002, Maharashtra, India.

Keywords:

Ketorolac Tromethamine, RP-HPLC method, Method development, Method validation, UV detector

Correspondence to Author:

Dhiraj Arvind Khairnar

Department of Pharmaceutics, M.V.P. Samaj's College of Pharmacy, Near K.T.H.M. Campus, Gangapur Road, Nasik - 422002, Maharashtra, India.

E-mail: bdhirukhairnar2011@gmail.com

\begin{abstract}
In the present study, a simple, precise, and accurate method was developed and validated for analysis of Ketorolac Tromethamine in Tablet formulation. A gradient HPLC analysis was performed on Grace C18 column $(250 \mathrm{~cm} \times 4.6 \mathrm{~mm} \times 5 \mu)$. The compound was separated with a solvent mixture of Methanol and water in a ratio of $65: 35 \mathrm{v} / \mathrm{v}$ with $0.1 \% \mathrm{O}$-phosphoric acid as the mobile phase at a flow rate of $1 \mathrm{ml} / \mathrm{min}$. The UV detection was performed at the $\kappa$ max 245 $\mathrm{nm}$. The retention time was found to be $7.70 \mathrm{~min}$. The system suitability parameters such as theoretical plate count, tailing factor, and percentage relative standard deviation (RSD) between six standard injections was within the limit. The method was validated according to the International conference of harmonization (ICH) guidelines. The linearity was found to be in the concentration range of $5-25 \mu \mathrm{gm} / \mathrm{ml}$ as indicated by correlation coefficient $\left(\mathrm{r}^{2}\right)$ of 0.999 . The robustness of the method was evaluated by deliberately altering the chromatographic condition. The developed method can be applicable for routine quantitative analysis.
\end{abstract}

INTRODUCTION: Ketorolac tromethamine is a non-steroidal anti-inflammatory drug (NSAID). Chemically 2-Amino-2-(hydroxymethyl) propane1, 3-diol (1RS) -5- benzoyl-2, 3-dihydro-1Hpyrrolizine-1-carboxylate (API) (European Pharmacopoeia 2008) as shown in Fig 1. It is a member of the heterocyclic acetic acid derivative family and is used as an analgesic with an efficacy close to that of the opioid family. It is also a potent antipyretic and anti-inflammatory. It is mainly used for the short term treatment of post-operative pain as it is highly selective for the COX-1 enzyme ${ }^{5}$.

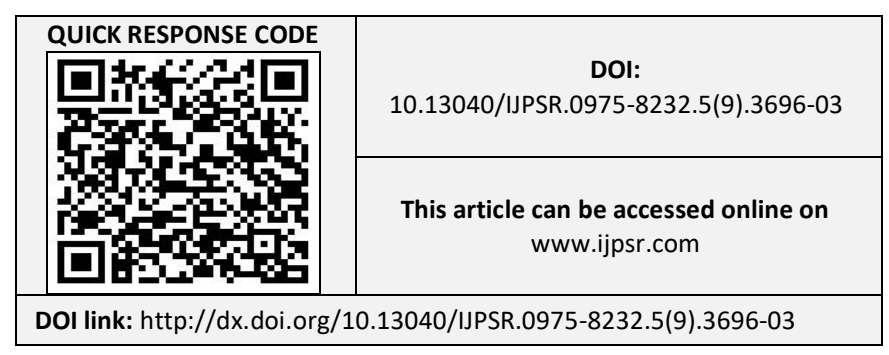

The USA Food and Drug Administration approves this Analgesic, and it is non-narcotic, fast acting, and non-addictive. It can be administered orally or by injection ${ }^{12}$.

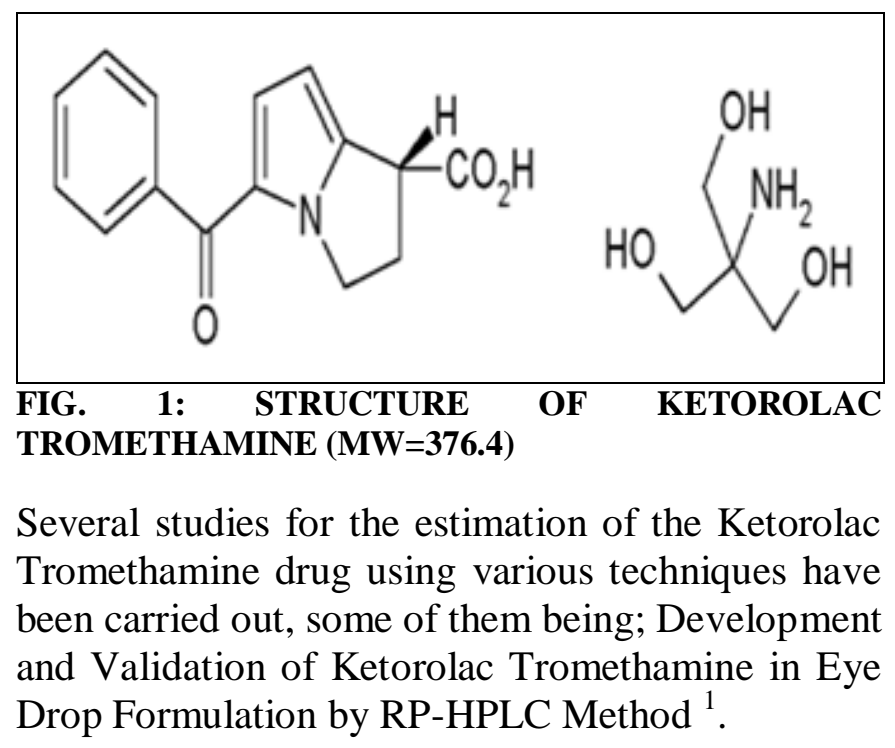


RP- HPLC method development and validation of acuvail drug ${ }^{2}$. New simultaneous UV-Visible spectrophotometric methods for estimation of ofloxacin and ketorolac tromethamine in ophthalmic dosage form ${ }^{3}$. Analytical method development and validation for the simultaneous estimation of febuxostat and ketorolac in tablet dosage forms by RP-HPLC ${ }^{4}$. Development and validation of a rapid liquid chromatographic method for the analysis of Ketorolac Tromethamine and its related production impurities 5 .

Simultaneous RP-HPLC estimation of moxifloxacin hydrochloride and ketorolac tromethamine in ophthalmic dosage forms ${ }^{8}$. New spectrophotometric determination of ketorolac tromethamine bulk and pharmaceutical dosage form ${ }^{9}$. Two-dimensional liquid chromatographyion trap mass spectrometry for the simultaneous determination of ketorolac enantiomers and paracetamol in human plasma application to a pharmacokinetic study ${ }^{11}$. Reversed-phase highperformance liquid chromatography of ketorolac and its application to bioequivalence studies in human serum ${ }^{12}$. A simple and sensitive method for the analysis of ketorolac in human plasma using high-performance liquid chromatography ${ }^{13}$. An indirect (derivatization) and a direct HPLC method for the determination of the enantiomers of ketorolac in plasma ${ }^{14}$.

\section{Experimental Procedures:}

Instrument: Younglin (S.K 9000) gradient System with UV Detector (Autochrome -3000 software), Sartorius Electronic Analytical balance, Crest sonicator, and Grace $\mathrm{C}_{18}$ column $(4.6 \mathrm{~mm} \times 250$ $\mathrm{cm} \times 5 \mu \mathrm{m})$ was used.

Chemical and Reagents: Gift sample of Ketorolac Tromethamine was obtained from FDC Limited, Mumbai. A Pharmaceutical product (Ketrol- DT) containing the same amount of drug formulation was used in the experiment HPLC grade methanol was procured from Modern lab, Nasik. HPLC grade deionized water was used throughout the experiment.

Mobile Phase: Methanol and Water with $0.1 \%$ OPhosphoric acid in a ratio of $65: 35 \mathrm{v} / \mathrm{v}$ used as mobile phase. It was used as diluents for the preparation of sample and standard.

\section{METHOD DEVELOPMENT:}

Wavelength Detection: Accurately weighed Ketorolac Tromethamine equivalent to $0.1 \mathrm{gm}$ in $100 \mathrm{ml}$ volumetric flask, $100 \mathrm{ml}$ methanol was added, sonicate for $5 \mathrm{~min}$ and filtered through 0.45 nylon membrane filter. Pipette out $1 \mathrm{ml}$ of the above solution and dilute to $10 \mathrm{ml}$ with methanol in $10 \mathrm{ml}$ volumetric flask and scanned between 200 $400 \mathrm{~nm}$ by UV spectroscopy. The $\lambda_{\max }$ found was $245 \mathrm{~nm}$.

Chromatographic Conditions: Chromatographic separation was achieved at ambient temperature, the detection was carried at $245 \mathrm{~nm}$ at a flow rate of $1 \mathrm{ml} / \mathrm{min}$, and run time was kept $16 \mathrm{~min}$. Before the injection of drug solution column was equilibrated for $60 \mathrm{~min}$ with the mobile phase flowing through the system. The injection volume was $20 \mu \mathrm{l}$ throughout the experiment. Blank containing mobile phase was injected to check the solvent interference.

Standard Preparation: The $10 \mathrm{mg}$ of Ketorolac Tromethamine was weighed and transferred into a $10 \mathrm{ml}$ volumetric flask and make up to the volume with methanol. From this take 0.05, 0.10, 0.15, 0.20 and $0.25 \mathrm{ml}$ and dilute with mobile phase up to 10 $\mathrm{ml}$ for preparation of 5,10,15, 20 and $25 \mu \mathrm{gm} / \mathrm{ml}$ respectively. A representative chromatogram of the standard was shown in Fig 2.

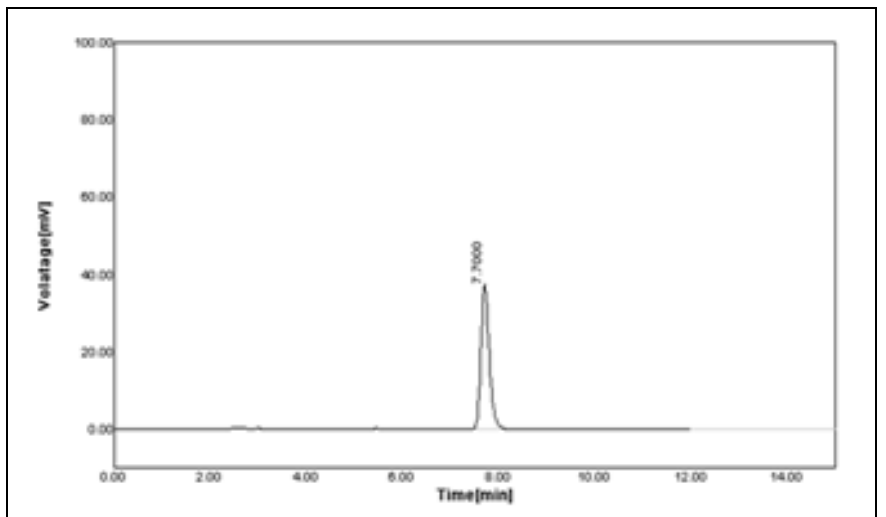

FIG. 2: STANDARD CHROMATOGRAM

Sample Preparation: The $220 \mathrm{mg}$ powder of Ketrol - DT contain $10 \mathrm{mg}$ Ketorolac tromethamine take in $10 \mathrm{ml}$ volumetric flask and make up the volume with methanol. Sonicated for $15 \mathrm{~min}$ and filtered through a $0.45 \mu \mathrm{m}$ nylon membrane filter. A representative chromatogram of the sample was shown in Fig. 3 and Table 1. 


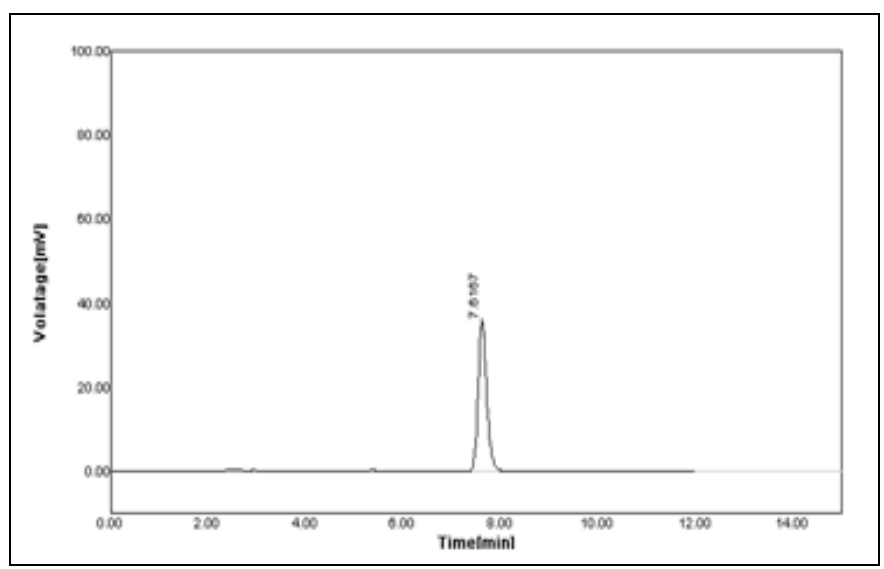

FIG. 3: SAMPLE CHROMATOGRAM

TABLE 1: ANALYSIS OF MARKETED FORMULATION

\begin{tabular}{cccccc}
\hline $\begin{array}{c}\text { Commercial } \\
\text { formulation }\end{array}$ & Ingredients & $\begin{array}{c}\text { Labeled amount } \\
(\mathbf{m g})\end{array}$ & Area & $\begin{array}{c}\text { Amount found } \\
(\mathbf{m g})\end{array}$ & \% found \\
\hline Ketrol - DT & $\begin{array}{c}\text { Ketorolac } \\
\text { Tromethamine } \\
\text { Ketorolac }\end{array}$ & $10 \mathrm{mg}$ & 365.8 & 10.14 & 100.70 \\
Ketrol - DT & $10 \mathrm{mg}$ & 368.75 & 10.32 & 101.60 \\
\hline
\end{tabular}

Evaluation of System Suitability Evaluation of System Suitability: The $20 \mu \mathrm{l}$ of the standard solution was injected in six duplicate before and after the analysis, and the chromatogram was recorded. System suitability parameter like column efficiency, plate count, and tailing factor were also recorded. The column efficiency was determined was found to be more than 2000 USP plate count, USP Tailing for the same peak is not more than 2.0 and \% RSD of six injections of the standard solution is not more than $2.0 \%$ the chromatogram was shown in Fig. 4 and Table 2.

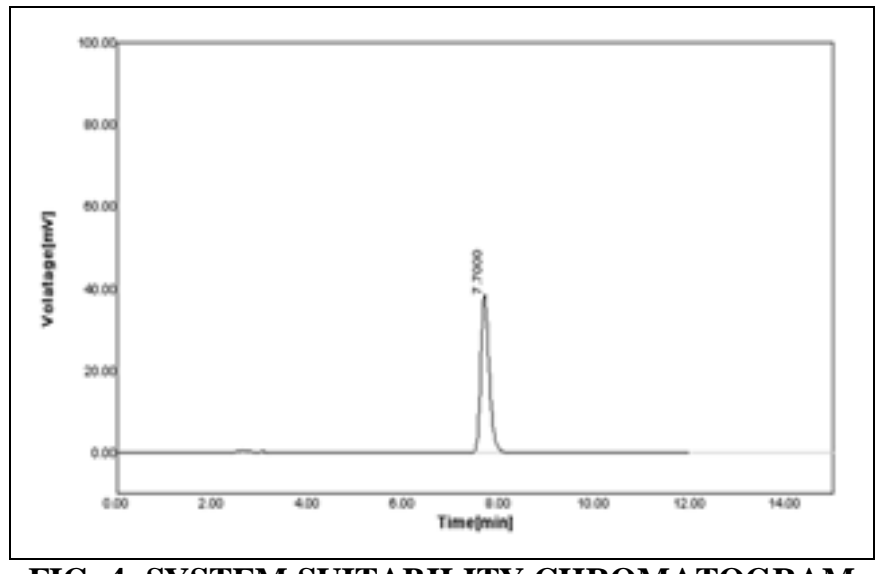

TABLE 2: SYSTEM SUITABILITY STUDY

\begin{tabular}{ccccc}
\hline Injections & USP Plate count & USP Tailing Factor & RT & Peak Area (min) \\
\hline 1 & 8219 & 1.22 & 7.700 & 450.25 \\
2 & 8362 & 1.35 & 7.766 & 453.17 \\
3 & 8398 & 1.22 & 7.783 & 462.70 \\
4 & 8219 & 1.22 & 7.700 & 460.36 \\
5 & 6943 & 1.22 & 7.666 & 457.58 \\
6 & 8324 & 1.25 & 7.712 & 452.77 \\
& & Mean & 7.721 & 456.13 \\
& & SD & 0.0444 & 4.8535 \\
& & \%RSD & 0.5750 & 1.064 \\
\hline
\end{tabular}


Analytical Method Validation:

Linearity: The linearity of Ketorolac Tromethamine was determined by preparing and injecting solution with a concentration of about 5$25 \mu \mathrm{gm} / \mathrm{ml}$. The calibration curve indicates the response is linear over the concentration range studied for Ketorolac Tromethamine with correlation coefficient (r) of 0.999. Calibration curve for linearity shown in Fig. $\mathbf{5}$ and their values in Table 3.

TABLE 3: LINEARITY

\begin{tabular}{ccccccc}
\hline S. no. & Conc. $(\boldsymbol{\mu g m} / \mathbf{m l})$ & Area I & Area II & Mean & SD & \% RSD \\
\hline 1 & 5 & 103.12 & 106.00 & 104.56 & 2.04 & 1.95 \\
2 & 10 & 195.70 & 192.72 & 194.21 & 2.11 & 1.08 \\
3 & 15 & 285.38 & 283.32 & 284.35 & 1.46 & 0.81 \\
4 & 20 & 357.56 & 362.75 & 360.16 & 3.67 & 1.02 \\
5 & 25 & 450.39 & 444.36 & 447.38 & 4.26 & 0.85 \\
\hline
\end{tabular}

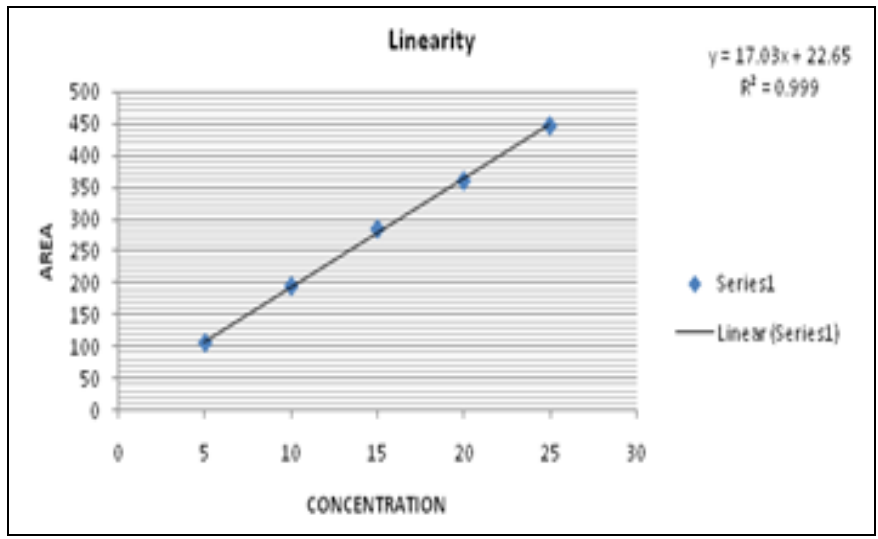

FIG. 5: CALIBRATION CURVE FOR KETOROLAC TROMETHAMINE

Precision: Precision was measured in terms of repeatability of application and measurement. Repeatability of standard application (system precision) was carried out using six replicate of the sample injection $(25 \mu \mathrm{gm} / \mathrm{ml})$ repeatability of sample measurement (method precision) was carried out in six replicate of sample preparation from the same homogenous blend of the marketed sample $(25 \mu \mathrm{gm} / \mathrm{ml})$. The percentage RSD for repeatability of standard preparation was $1.18 \%$ whereas the \% RSD for repeatability of the sample $0.79 \%$. This shows that the precision of the method is satisfactory as percentage RSD is not more than $2 \%$ the chromatogram was shown in Table 4 and 5.

TABLE 4: PRECISION STUDY OF THE SYSTEM

\begin{tabular}{cccc}
\hline $\begin{array}{c}\text { S. } \\
\text { no. }\end{array}$ & $\begin{array}{c}\text { Sample } \\
\text { Area }\end{array}$ & $\begin{array}{c}\text { \% Assay } \\
\text { Present }(\boldsymbol{\mu g m})\end{array}$ & Amount \\
\hline 1 & 450.25 & 100.40 & 25.10 \\
2 & 453.17 & 101.08 & 25.27 \\
3 & 462.70 & 103.32 & 25.83 \\
4 & 460.36 & 102.80 & 25.70 \\
5 & 457.58 & 102.12 & 25.53 \\
6 & 450.25 & 102.70 & 25.60 \\
& Mean & 101.94 & 25.49 \\
& SD & 1.20 & 0.30 \\
& \% RSD & 1.18 & 1.18 \\
\hline
\end{tabular}

TABLE 5: PRECISION STUDY OF THE METHOD

\begin{tabular}{cccc}
\hline S. no. & $\begin{array}{c}\text { Sample } \\
\text { area }\end{array}$ & $\begin{array}{c}\% \\
\text { Assay }\end{array}$ & $\begin{array}{c}\text { Amount } \\
\text { present }(\boldsymbol{\mu g m})\end{array}$ \\
\hline 1 & 451.37 & 100.48 & 25.12 \\
2 & 456.21 & 101.36 & 25.34 \\
3 & 463.67 & 101.80 & 25.45 \\
4 & 459.36 & 102.60 & 25.65 \\
5 & 456.48 & 101.72 & 25.43 \\
6 & 454.23 & 100.56 & 25.14 \\
& Mean & 101.42 & 25.35 \\
& SD & 0.8066 & 0.2016 \\
& \% RSD & 0.795 & 0.795 \\
\hline
\end{tabular}

The inter-day precision also carries out using 10 , 15 , and $25 \mu \mathrm{gm} / \mathrm{ml}$ standard solution $\%$ RSD found is not more than 2\% shown in Fig. 6 and Table 6.

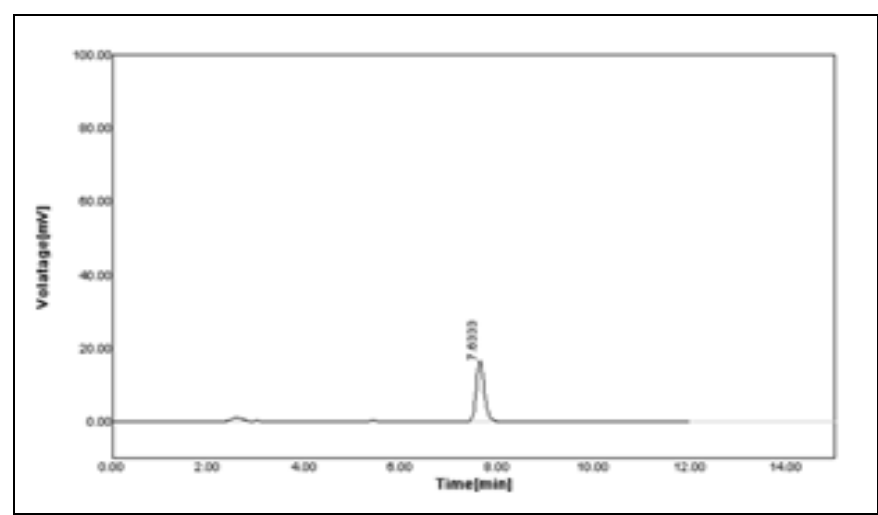

FIG. 6: PRECISION CHROMATOGRAM 
TABLE 6: PRECISION (INTERDAY)

\begin{tabular}{ccccccc}
\hline S. no. & Conc. & Area I & Area II & Mean & SD & RSD \\
\hline 1 & 10 & 194.16 & 192.93 & 193.55 & 0.87 & 0.45 \\
2 & 15 & 277.23 & 283.71 & 280.47 & 4.58 & 1.63 \\
3 & 20 & 441.46 & 445.94 & 443.70 & 3.17 & 0.71 \\
\hline
\end{tabular}

Accuracy: The percentage of recovery experiments were performed by adding a known quantity of pure standard drug into the pre-analysed sample. The solution equivalent to $100 \mathrm{mg}$ of Ketorolac tromethamine was accurately weighed into a 100 $\mathrm{ml}$ volumetric flask. The sample was then spiked with the standard at level $80 \%, 100 \%$ and $120 \%$ of test concentration. The resulting spiked sample solutions were assayed in triplicate, and the results were compared and expressed as a percentage. The mean percentage recovery of Ketorolac Tromethamine was found to be in the range between 101.7 and 103.6, which are within the acceptance limit was shown in Table 7 and Fig 7.

TABLE 7: ACCURACY STUDY

\begin{tabular}{cccccc}
\hline Spiked level & Amount added $\boldsymbol{\mu g m} / \mathbf{m l}$ & Peak area & Amount found & Percent recovery & Percent mean recovery \\
\hline $80 \%$ & \multirow{2}{*}{8} & 341.98 & 18.75 & 104.1 & 103.6 \\
$80 \%$ & & 344.55 & 18.90 & 105.0 & 101.9 \\
$80 \%$ & & 343.25 & 18.35 & 102.8 & 101.7 \\
$100 \%$ & \multirow{2}{*}{10} & 372.86 & 20.56 & 100.6 & \\
$100 \%$ & & 365.37 & 20.12 & 101.9 & 102.8 \\
$100 \%$ & & 368.42 & 20.39 & 103.2 & 102.2 \\
$120 \%$ & \multirow{2}{*}{12} & 409.56 & 22.71 & 103.0 & \\
$120 \%$ & & 405.88 & 22.50 & \\
$120 \%$ & & 407.29 & 22.67 & & \\
\hline
\end{tabular}

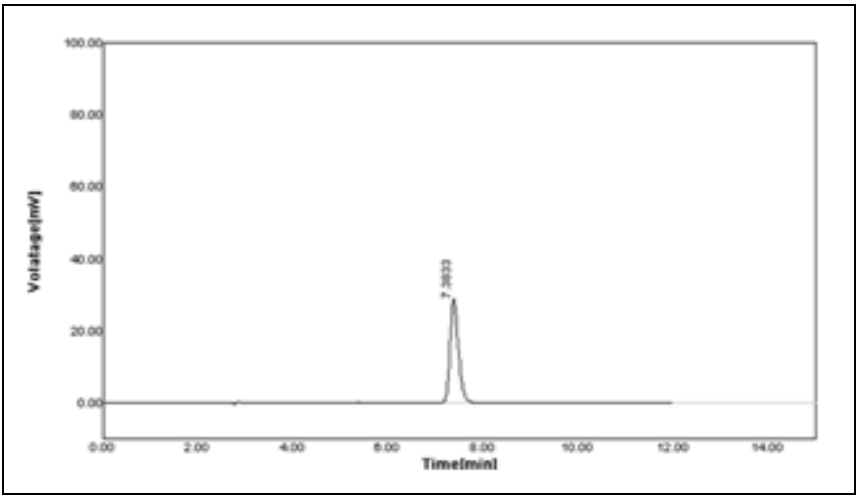

FIG. 7: ACCURACY CHROMATOGRAM
Robustness: Robustness of the method was determined by analyzing the standard solution at normal operating condition by changing some operating analytical conditions such as flow rate, mobile phase, and detection wavelength. The condition with variation and their result was shown in Table 8. The tailing factor is around indicative of peak symmetry and theoretical plate count also above 2000. Hence robustness of the extent of variations applied to the analytical condition was shown in Fig. 8.

TABLE 8: ROBUSTNESS STUDIES

\begin{tabular}{ccccc}
\hline System suitability & Parameter (variation) & $\begin{array}{c}\text { \% RSD of peak } \\
\text { area response }(\mathbf{n}=3)\end{array}$ & $\begin{array}{c}\text { Mean tailing } \\
\text { factor }(\mathbf{n}=\mathbf{3})\end{array}$ & $\begin{array}{c}\text { Mean retention } \\
\text { time }(\mathbf{n}=\mathbf{3})\end{array}$ \\
\hline Flow change & $0.9 \mathrm{ml} / \mathrm{min}$ & 1.61 & 1.27 & 8.23 \\
Mobile phase volume & $1.1 \mathrm{ml} / \mathrm{min}$ & 1.29 & 1.25 & 6.68 \\
& $64: 36$ & 1.81 & 1.18 & 7.73 \\
Wavelength change & $66: 34$ & 1.56 & 1.15 & 7.15 \\
& $244 \mathrm{~nm}$ & 1.18 & 1.20 & 7.67 \\
\hline
\end{tabular}

Limit of Detection (LOD) and Limit of Quantification (LOQ): The limit of detection (LOD) is the the lowest amount of analyte in a sample that can be detected but not necessarily quantified, under the stated experimental conditions. LOD and LOQ were calculated by using standard deviation and slope value obtained from the calibration curve by using formula LOD =
$3.3(\mathrm{SD} / \mathrm{S})$ and $\mathrm{LOQ}=10(\mathrm{SD} / \mathrm{D})$. The $\mathrm{LOD}$ and LOQ value for Ketorolac Tromethamine was found to be $0.825 \mu \mathrm{gm} / \mathrm{ml}$ and $2.501 \mu \mathrm{gm} / \mathrm{ml}$, respectively.

\section{Force Degradation Study:}

Thermal Degradation: Heat about $1000 \mathrm{mg}$ of tablet powder at $105^{\circ} \mathrm{C}$ for $24 \mathrm{~h}$ weigh accurately 
this powder equivalent to $100 \mathrm{mg}$ of Ketorolac Tromethamine into a $100 \mathrm{ml}$ volumetric flask added $60 \mathrm{ml}$ of diluent and sonicate $15 \mathrm{~min}$ with intermittent shaking and makeup to the mark with diluent. Thermal degradation study was carried out after 1 day, 3 day, and 6day shown in Fig. 9.

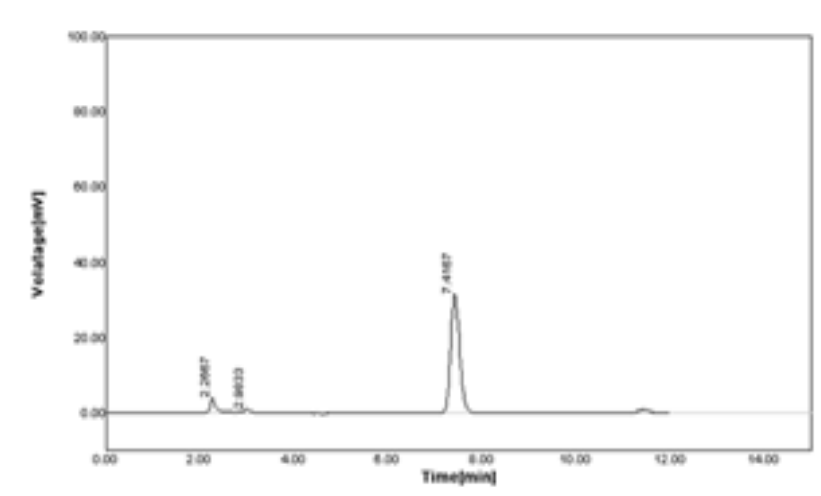

FIG. 9: THERMAL STRESS CONDITION

Photostability: Expose about $1000 \mathrm{mg}$ of tablet powder in photostability for 1.2 million Lux $\mathrm{h}$ weigh accurately this powder equivalent to $100 \mathrm{mg}$ of Ketorolac tromethamine into a $100 \mathrm{ml}$ volumetric flask add $60 \mathrm{ml}$ of diluent and sonicate for 15 min with intermittent shaking and makeup to the mark with diluent. Filter the solution through a $0.45 \mu$ nylon filter. Photostability was carried out after 1 day, 3 day and 6 days shown in Fig. 10.

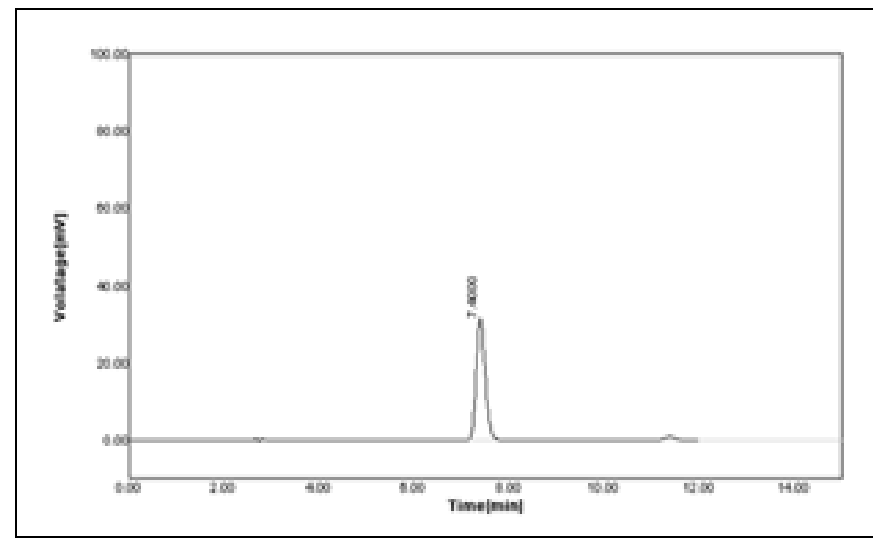

\section{FIG. 10: PHOTODEGRADATION STUDY CHROMATOGRAM}

Acid Degradation: Weight accurately tablets powder equivalent to $100 \mathrm{mg}$ of Ketorolac tromethamine into $100 \mathrm{ml}$ volumetric flask add 10 $\mathrm{ml}$ of $5 \mathrm{~N}$ Hydrochloric acid heat it on water bath at $80{ }^{\circ} \mathrm{C}$ for $8 \mathrm{~h}$, cool it add $10 \mathrm{ml}$ of $5 \mathrm{~N}$ Sodium Hydroxide and add $60 \mathrm{ml}$ of diluent and sonicate, dissolved the substances, makeup to the mark with diluent and mix well. Filter the solution through
$0.45 \mu$ nylon filter. The Chromatogram is shown in Fig. 11.

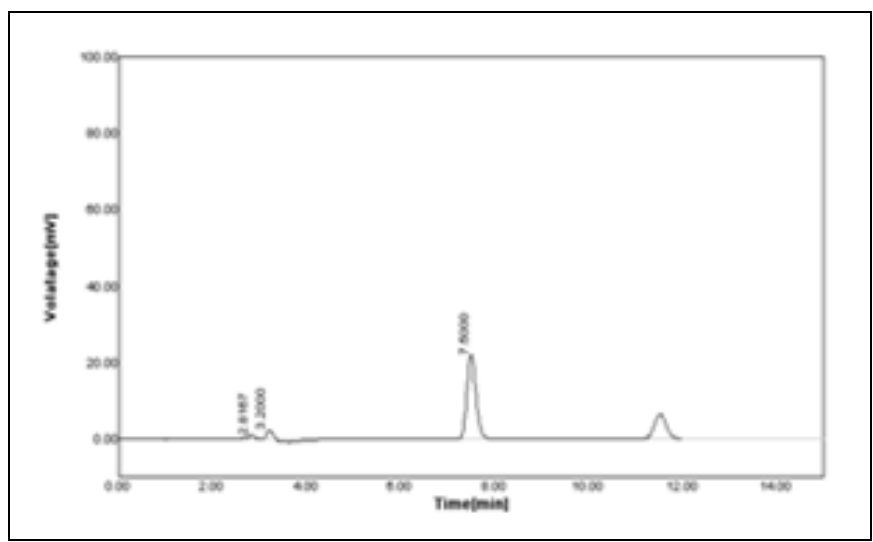

FIG. 11: ACID STRESS CONDITION

Base Degradation: Weight accurately tablets powder equivalent to $100 \mathrm{mg}$ of Ketorolac tromethamine into $100 \mathrm{ml}$ volumetric flask add 10 $\mathrm{ml}$ of $5 \mathrm{~N}$ Sodium Hydroxide heat it on water bath at $80{ }^{\circ} \mathrm{C}$ for $8 \mathrm{~h}$, cool it add $10 \mathrm{ml}$ of $5 \mathrm{~N}$ Hydrochloric acid and add $60 \mathrm{ml}$ of diluent and sonicate, dissolved the substances, makeup to the mark with diluent and mix well. Filter the solution through $0.45 \mu$ nylon filter. Chromatogram showed in Fig. 12.

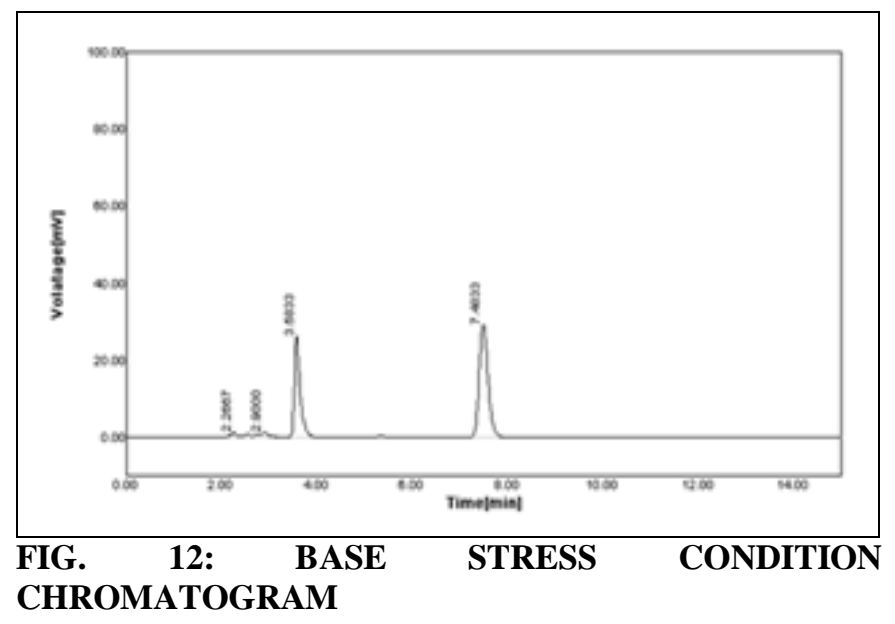

Peroxide Degradation: Weight accurately tablets powder equivalent to $100 \mathrm{mg}$ of Ketorolac tromethamine into $100 \mathrm{ml}$ volumetric flask add 10 $\mathrm{ml} 30 \%$ hydrogen peroxide heat it on a water bath at $80{ }^{\circ} \mathrm{C}$ for $8 \mathrm{~h}$, add $60 \mathrm{ml}$ of diluent and sonicate, dissolved the substances, makeup to the mark with diluent and mix well. Filter the solution through $0.45 \mu$ nylon filter. Chromatogram and force degradation data, as has shown in Fig. 13 and Table 9, respectively. 


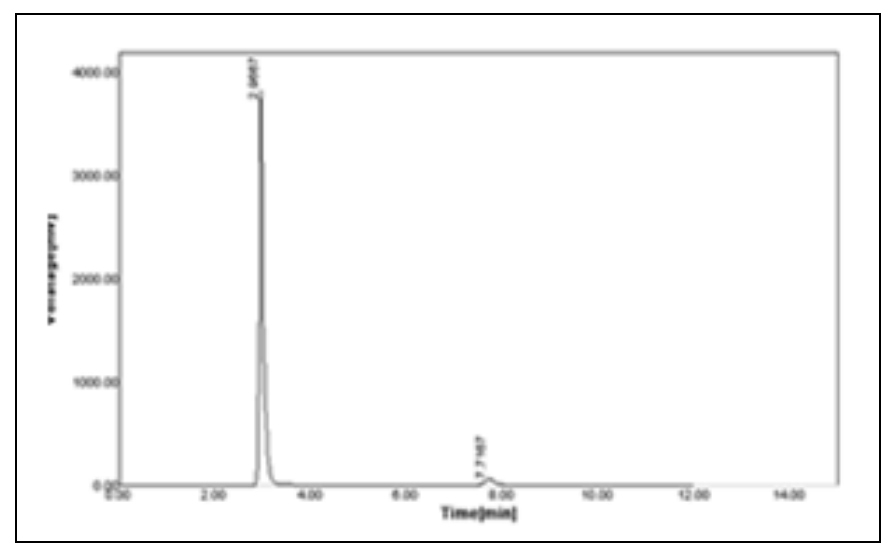

FIG. 13: PEROXIDE STRESS CONDITION

TABLE 9: FORCE DEGRADATION DATA

\begin{tabular}{cccc}
\hline $\begin{array}{c}\text { Treated } \\
\text { Parameter }\end{array}$ & RT & $\begin{array}{c}\text { Theoretical } \\
\text { plate }\end{array}$ & $\begin{array}{c}\text { Tailing } \\
\text { factor }\end{array}$ \\
\hline As such Ketorolac & 7.88 & 8615.4 & 1.27 \\
$\begin{array}{c}\text { Thermal treatment } \\
\text { After 1day }\end{array}$ & 7.41 & 6497.6 & 1.12 \\
3 day & 7.40 & 6468.4 & 1.16 \\
6 day & 7.33 & 6352.4 & 1.12 \\
Photo Stability & & & \\
After 1day & 7.40 & 6468.4 & 1.12 \\
$\quad$ 3 day & 7.43 & 6526.8 & 1.12 \\
6 day & 7.36 & 6410.4 & 1.05 \\
Acid heat treatment & 7.50 & 6644.4 & 1.12 \\
Base after heating & 7.45 & 7694.3 & 1.12 \\
$\begin{array}{c}\text { Oxidation } \\
\text { treatment } \\
\text { after heat }\end{array}$ & 7.71 & 6064.9 & 1.11 \\
\hline
\end{tabular}

RESULTS AND DISCUSSION: A different combination of mobile phases and chromatographic conditions were tried and a mobile phase containing methanol and water with $0.1 \%$ Ophosphoric acid (65:35 v/v), Grace C18 $(250 \mathrm{~cm} \times$ $4.6 \mathrm{~mm} \times 5 \mu$ ) column, $1.0 \mathrm{mLmin}-1$ flow rate, 20 $\mu \mathrm{L}$ injection volume, $30{ }^{\circ} \mathrm{C}$ column oven temperature, $245 \mathrm{~nm}$ wavelength and $16 \mathrm{~min}$ run time was found to be suitable for all combinations. These chromatographic conditions gave a retention time of $7.70 \mathrm{~min}$. The force degradation study of the sample solution was evaluated by preparing a sample solution as per the proposed method and analyzed after 1 day, 3day and 6 days for thermal and photostability study retention time found same as per standard chromatogram. System precision and method precision results showed the \% RSD of 1.18 and 0.79 , respectively. A good linearity relationship indicated by correlation coefficient (r) value 0.999 was observed between the

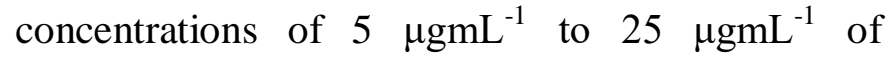
Ketorolac Tromethamine. Inter-day Precision was done by changing the analyst, column, with the same chromatographic conditions, and the obtained results were within limits. The Robustness method was evaluated by deliberately varying the chromatographic conditions of the method, such as mobile phase methanol content, flow rate, and wavelength. The parameter like tailing factor and retention time showed adherence to the limits. The accuracy of the method was determined, and the percentage of recovery was calculated. The data indicates an average of $103.6 \%$ recovery of the standard sample.

CONCLUSION: The method developed for Ketorolac Tromethamine was found to be a simple process and the procedure does not involve any experimental conditions. The validation results indicated that the method was specific, accurate, linear, precise, rugged and robust. The runtime was relatively $20 \mathrm{~min}$ which enabled rapid quantification of many samples in routine and quality control analysis of tablet formulation.

ACKNOWLEDGEMENT: We are thankful to Prof. D. V. Derle, Principal of M.V.P. Samaj's College of Pharmacy, Nashik for providing the facility to carry out the research work.

\section{CONFLICT OF INTEREST: Nil}

\section{REFERENCES:}

1. Sunil G, Jambulingam M, Thangadurai AS, Kamalakannan $\mathrm{D}$, Sundaraganapathy $\mathrm{R}$ and Jothimanivannan $\mathrm{C}$ : Development and validation of ketorolac tromethamine in eye drop formulation by RP-HPLC method. Arabian Journal of Chemistry 2012; 1-21.

2. Babu NB, Rao SP and Raju RR: RP HPLC Method Development and Validation of Acuvail Drug. International Journal of Research in Pharmaceutical and Biomedical Sciences 2011; 2(1): 128-29.

3. Vijaya V, Vrushali T, Joshi SV and Dhole SN: New Simultaneous UV-Visible spectrophotometric methods for estimation of ofloxacin and ketorolac tromethamine in ophthalmic dosage form. Asian J Pharm Ana 2013; 3(2): 53-57.

4. Raja B and Rao AL: Analytical method development and validation for the simultaneous estimation of Febuxostat and Ketorolac in tablet dosage forms by RP-HPLC. International Journal of Pharmaceutical, Chemical and Biological Sciences 2013; 3(3): 571-76.

5. Connor ON, Geary $\mathrm{M}$, Wharton $\mathrm{M}$ and Curtin L: Development and validation of a rapid liquid chromatographic method for the analysis of Ketorolac Tromethamine and its related production impurities. Journal of Applied Pharmaceutical Science 2012; 2(5): 1521.

6. Vaibhav S, Mohit M and Sadhana R: Validation of RPHPLC method for simultaneous estimation of febuxostat and Diclofenac potassium in bulk drug and bilayer tablet 
formulation. International Research Journal of Pharmacy 2013; 4(9): 103-06.

7. Shraddha P, Manan R and Umang S: Development and validation of spectrofluorimetric method for the estimation of moxifloxacin in pharmaceutical dosage form. International Journal of Pharmacy and Pharmaceutical Sciences 2013; 5(4): 252-54.

8. Dharti P, Mehul P and Ketan P: Simultaneous RP-HPLC estimation of moxifloxacin hydrochloride and ketorolac tromethamine in ophthalmic dosage forms. Asian $\mathbf{J}$ Research Chem 2012; 5(5): 698-00.

9. Pratapareddy AJ and Chakravarthi IE: New spectrophotometric determination of ketorolac tromethamine bulk and pharmaceutical dosage form. International Journal of Pharmaceutical Sciences and Res 2012; 3(12): 4848-50.

10. Kunagu VS and Janardhan M: Development and validation of stability-indicating RP-HPLC method for estimation of moxifloxacin in moxifloxacin $\mathrm{HCl}$ tablets $400 \mathrm{mg}$. International Journal of Pharmaceutical Invention 2012; 2(7): 24-33

11. Ing-Lorenzini KR, Desmeuels JA and Besson M: Twodimensional liquid chromatography-ion trap mass spectrometry for the simultaneous determination of Ketorolac enantiomers and paracetamol in human plasma Application to a pharmacokinetics study. Journal of Chromatography A 2009; 1216: 3851-56.

12. Chaudhary RS, Gangwal SS, Jidal KC and Khanna S: Reversed-phase high-performance liquid chromatography of Ketorolac and its application to bioequivalence studies in human serum. Journal of Chromatography 1993; 614: 180-84.

13. Muralidharan S, Kumar KJ and Parasuraman S: Simple and sensitive method for the analysis of ketorolac in human plasma using high-performance liquid chromatography. Journal of Young Pharmacists 2013; 5: 98-01.

14. Tsina I, Tam LT, Boyd A, Rocha C, Massey I and Tarnowski T: An indirect (derivatization) and a direct HPLC method for the determination of the enantiomers of Ketorolac in plasma. Journal of Pharmaceutical and Biomedical Analysis 1996; (15): 403-17.

15. ICH, International Conference on Harmonisation ( ICH) Q2 (R1): Validation of analytical procedures: Test and methodology, Geneva, Switzerland 2005.

How to cite this article:

Khairnar DA, Chaudhari CS and Anantwar SP: Method development and validation of ketorolac tromethamine in tablet formulation by RP-HPLC method. Int J Pharm Sci \& Res 2014; 5(9): 3696-03. doi: 10.13040/IJPSR.0975-8232.5(9).3696-03.

All @ 2013 are reserved by International Journal of Pharmaceutical Sciences and Research. This Journal licensed under a Creative Commons Attribution-NonCommercial-ShareAlike 3.0 Unported License.

This article can be downloaded to ANDROID OS based mobile. Scan QR Code using Code/Bar Scanner from your mobile. (Scanners are available on Google Playstore) 